\title{
Lifestyles and Their Impact on Energy-Related Investment Decisions
}

\author{
Maria Gröger, Victoria Schmid, Thomas Bruckner
}

Institute for Infrastructure and Resources Management, University of Leipzig, Leipzig, Germany.

Email: mgroeger@wifa.uni-leipzig.de

Received May 3 $3^{\text {rd }}$, 2011; revised May 23 ${ }^{\text {rd }}, 2011$; accepted June $2^{\text {nd }}, 2011$.

\begin{abstract}
This paper presents an empirical survey of energy-related investment decisions made by private households in Germany. The investment behaviour is segmented and discussed by applying the milieu approach. The decision makers are clustered in certain lifestyles, as represented by the Sinus-Milieus ${ }^{\circledR}$ from the Sinus Institute. To analyse the relationship between the lifestyles of house owners and their energy-related investment decisions, telephone interviews were conducted in order to acquire data on currently installed heating systems and preferences for future heating systems in private residential buildings. The results of the survey support the hypothesis of a link between lifestyles and the energy-related investment behaviour. Based on the observed relationship between lifestyles and decisions on energy technologies, predictions of energy trends in private residential buildings can be improved. In addition, the knowledge about specific development paths allows the utilisation of the information for information campaigns and the promotion of energy supply technologies which lead to lower $\mathrm{CO}_{2}$-emissions.
\end{abstract}

Keywords: Lifestyles, Consumers, Survey, Space Heating Technology

\section{Introduction - Rationale for the Approach}

Private consumption, especially energy consumption, is one of the largest demand classes in most economies, and is therefore responsible for a major fraction of global emissions. Reducing energy use and related emissions in private households is an important step towards a more sustainable future in a carbon neutral economic society. In industrialised countries, the energy consumption in private households is dominated by the heating energy demand; indeed, with $67 \%$ space-heating is still the largest household energy end-use in the EU [1]. Many studies [2-5] show that the use of fossil fuels for heating could be reduced significantly by more efficient heating systems, the use of renewable energies and an energy efficient retrofitting of buildings. However, the extent to which the theoretical reduction potential can be realized depends on individual decision processes. For instance, residential heat demand depends on the energy consumption behaviour of building owners. Such behaviour can be subdivided into two consumption profiles:

Operational decisions of private households, e.g. using hot water and selecting an indoor temperature, are made intuitively and may not be changed expeditiously [6]. However, in order to be able to make energy-related in- vestment decisions, different technology options, the future energy demand and the estimated costs have to be considered. The study presented in this paper focuses on such investment decisions related to energy conversion technologies, which largely influence the final energy demand of buildings ( $c f$. Figure 1). In doing so, this study concentrates on investment decisions in the residential sector which are undertaken by private building owners.

Diffusion of distributed energy technologies affects the entire urban energy system. Thus, environmental innovations (e.g. the use of renewable energy) in this field are an important step towards a sustainable future. Using lifestyles is a possible approach for conducting research on environmental innovations in the context of energy consumption $[7,8]$. That data is complemented with findings from sociology, which indicate that a society can be clustered into social milieus [9]. This empirical sociological research has revealed that most people in a society are not homogeneous. They differ with respect to their preferences and knowledge, their ability to explore and process information, and therefore exhibit individual rates of acceptance of energy technologies. Consequently, Rogers [10] and Vishwanath [11] differentiate people according to their innovativeness because of the impact 


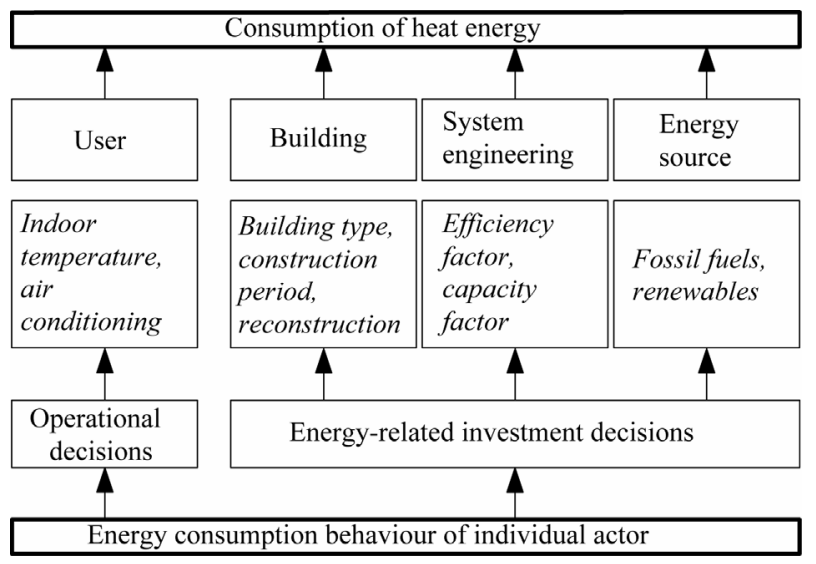

Figure 1. Different influences affecting heat energy consumption.

of personality on the adoption or rejection of innovation.

Lifestyle-related, target-group segmentation is used in social scientific environmental research to assess the relationship between attitudes and environment-related behaviour. The influence of lifestyles on a sustainable environmental development in general [12-14] and energy consumption in particular $[15,16]$ has been discussed frequently, but not yet conclusively. Today, there is a broad consensus that energy consumption by a society is not only influenced by technical aspects (e.g. efficiency) but also by socio-demographic aspects (e.g. age, education, size of households) and the lifestyles of consumers.

The application of the lifestyle approach to environmental research is motivated by the assumption that environmentally compatible behaviour can only be promoted by considering behaviour patterns of different lifestyle groups $[17,18]$. This assumption has been adopted by studies that investigate the segmentation of consumers with regard to their energy using behaviour [19] and by studies on the acceptance of nature conservation measures [20].

Studies that have been conducted thus far indicate that not only energy consumption, but also energy-related investment decisions can be assessed with the aid of the milieu approach. According to ecological consumer research [21,22], the individual energy-related investment behaviour is a strategic decision.

Lifestyle research has been primarily influenced by the milieu approach developed in the field of market research. Well-known models used both in science and marketing are the lifestyle approaches developed by Schulze [23] and the Sinus Institute. The Sinus-Milieus ${ }^{\circledR}$ have been established as a science-based model. They are continuously kept up-to-date by utilising the results of secondary research and information obtained by the monitoring socio-cultural trends. Today they are broadly used for market research and scientific research related to sustainability and environmental research [24]. For example, the future behaviour of private households with regard to their water consumption was analysed using the Sinus-Milieus ${ }^{\circledR}[25]$.

The results obtained confirm that energy-related investments by private households can be clustered and evaluated by using the lifestyle concept. The motivation for the present study was the hypothesis that an analysis of private decisions could deliver more profound knowledge about expected rates of future house renovations and preferred heating technologies. Understanding consumer behaviour is a prerequisite for actor-oriented and target-group specific approaches that attempt to promote a reduction in the residential heat demand. Thus, the following empirical approach, which was designed to investigate energy-related investment decisions made by private households, attempts to analyse to what extent a relationship between the lifestyle of house owners and their investment decisions concerning energy technologies exist. To this end, telephone interviews were conducted as part of this study in order to acquire data on currently installed heating systems and preferences for future heating systems in private residential buildings.

In part 2 of this paper the applied target-group model and the methodology of the empirical analysis are described. In part 3 the main findings of the survey are presented and discussed. Finally, the most important lessons learnt are summarised and their importance for further research is discussed.

\section{Empirical Survey}

\subsection{Lifestyle Approach}

A possible segmentation of lifestyle clusters is provided by the Sinus-Milieus ${ }^{\circledR}$. The underlying scientific model groups people according to their attitudes towards life and their ways of life. Fundamental value orientations as well as attitudes towards family, partnership, work, leisure activities, culture, money and consumption are regarded as being influential on lifestyle typology. The evaluation applied provides interesting results for consumer and market research. In addition, it not only allows an analysis of the survey results that reflects socio-demographic criteria but also one of socio-cultural characteristics.

The Sinus Institute has applied this milieu concept in 18 countries so far. Therefore, Sinus-Milieus ${ }^{\circledR}$ are developed and validated individually for each country. Figure 2 shows the classification of the ten Sinus-Milieus ${ }^{\circledR}$ according to the social classes and value orientation of the German population. Figure 2 points also out overlaps of some milieus as it is not possible to draw 


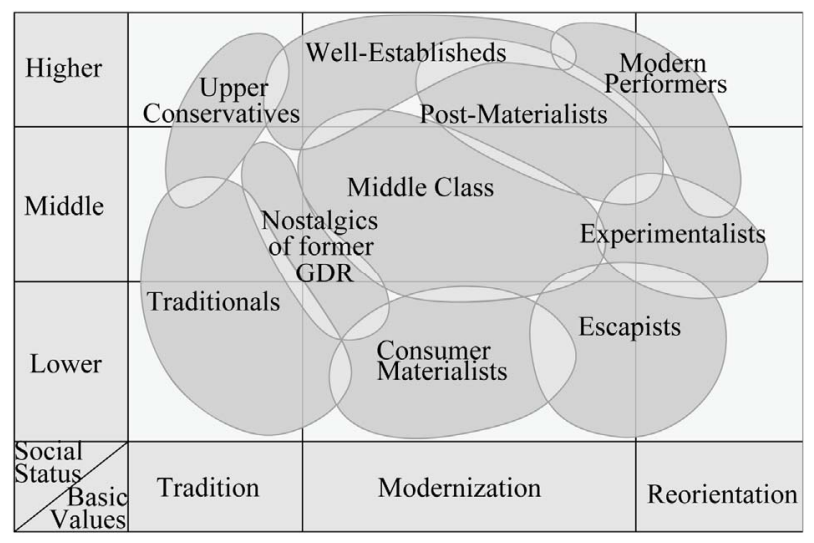

Figure 2. The Sinus-Milieus ${ }^{\circledR}$ in Germany used in the empirical study. Source: Sinus Sociovision.

exact boundaries between the lifestyle types. Thus, for strategic investigations the individual milieus are often compressed into four segments (Table 1).

In order to investigate the social diffusion processes of technological innovations, two important milieu groups should be distinguished:

Modern Performers are important representatives of the Social Leaders class. They represent a young, unconventional and likewise very educated milieu. They have high incomes and show a willingness to spend higher prices for quality and environmental friendly products. However, they exhibit an extremely resource-intensive lifestyle, which is characterized by a relatively high land and energy consumption. Modern Performers belong to a milieu that is willing to adapt to innovations quickly. As a consequence, they make significant contributions to the standards of a society. The other milieus orient themselves according to set trends and standards and adapt their behaviour to them. With their climate-friendly attitude towards renewable energies, Modern Performers have a role model function and play an important role in the environmental and sustainable communication [26].

The Middle Class belongs to the Mainstream and characterises the society's average age, education, and income. However, their resource use and their willingness to pay higher prices for environmental friendly products are slightly above the average of the population as a whole. The Middle Class is one of the milieus which is resistant to innovations. The focus of this milieu group is on stability. Decisive for the adaption or refusal of innovations is the degree of uncertainty related to the innovation [26].

Using basic values and attitudes from a questionnaire comprising 45 questions, the marketing company Sinus Sociovision divides the German population into ten Sinus-Milieus ${ }^{\circledR}$. For the study described in this paper, the Sinus Institute provided the respective questions to be included into the questionnaire on lifestyle-related in-
Table 1. Classification of the Sinus-Milieus ${ }^{\circledR}$.

\begin{tabular}{cc}
\hline Segment & Sinus-Milieu ${ }^{\circledR}$ \\
\hline \multirow{2}{*}{ Social Leaders } & Modern Performers \\
& Well-Establisheds \\
Mainstream & Post-Materialists \\
& Middle Class \\
Traditionalists & Consumer Materialists \\
& Upper Conservatives \\
& Traditionals \\
Hedonists & Nostalgics of former GDR \\
& Experimentalists \\
\end{tabular}

vestments. The answers of the respondents related to the Sinus-Milieus ${ }^{\circledR}$ were sent back to Sinus and coded into lifestyles by them. Therefore, the authors had no access to the cluster analysis used for generating the segmentation and are not allowed to publish the lifestyle-related questions.

The use of the Sinus-Milieus ${ }^{\circledR}$ for scientific analyses has been criticized because of this lack of information disclosure. However, the above-mentioned studies $[24,25]$ show that it is common to use the Sinus-Milieus ${ }^{\circledR}$ in the field of diffusion and sustainability research despite this disadvantage. In comparison to other classifications of milieus, the Sinus-Milieus ${ }^{\circledR}$ have the advantage that the company Microm is able to provide compatible, spatially referenced lifestyle data for Germany, Austria and Switzerland [27]. The lifestyle data is therefore available in a way appropriate for analysing the technical data for buildings (age, type etc.) - an aspect which is important for target-group-specific sustainability approaches.

\subsection{Method}

The empirical research consisted of a standardized questionnaire, conducted in Germany. The survey primarily addressed the attitude of the individual lifestyle groups towards different heating technologies.

The choice of people to be interviewed was based on a multi-stage random sample. The target group was property owners of one-family houses, double-family houses and row houses. For this purpose we relied on the willingness of the persons to take part in the interviews. The survey was conducted using a computer-assisted telephone interview, which took approx. 15 min. per interview. In total 471 building owners were asked to reveal their energy-related investment decisions. A total of 429 inquiries were completely filled out and evaluable. The evaluation covered a basic computation and a bivariate analysis based on the lifestyle aspect. 


\section{Empirical Findings}

\subsection{Descriptive Statistics}

Table 2 shows a summary of the main demographic characteristics of the sample. From the data appears that it is not a representative sample for Germany. The age of the test persons is between 17 and 92 years. The mean age $M d=57$ is above the federal average, likewise the educational level. $187(68 \%)^{1}$ participants mention a household income of 2,000 Euro and more. 214 (50\%) ${ }^{2}$ of the participants are gainfully employed, whereas the share of all employed people in Germany was $40 \%{ }^{3}$ in spring 2010.

The frequencies of the Sinus-Milieus ${ }^{\circledR}$ in the sample are presented in Figure 3, as well as a comparison of the average in Germany. The most represented are the PostMaterialists with 154 test persons (35.4\%). Together with the Modern Performers (33 people, 7.7\%) and the Well-Establisheds (92 people, 21.4\%) they form the Social Leaders. The Traditionalists are represented by the Upper Conservatives (31 people, 7.2\%), the Traditionals (21 people, 4.9\%) and the Nostalgics of former GDR (15 people, 3.5\%). The Consumer Materialists (10 people 2.3\%) and the Middle Class (44 people 10.3\%) represent the Mainstream. The Experimentalists (30 people, 7.0\%) and the Escapists (0.2\%) belong to the Hedonists. With just one test person the Escapists are strongly underrepresented.

The clear over-representation of Post-Materialists and Well-Establisheds can be traced back to the fact that both milieu groups live in houses above average [26] and so were qualified above average as target subject for the survey. Another reason could be the relatively high environmental orientation of these milieus, which would explain a higher willingness to participate in the telephone interview.

As in the present sample an equal size of the groups in regard to the lifestyles is not given (see Figure 3), the analysis of variance was not possible due to a missing homoscedasticity. Nevertheless, within the sample different attitudes of the lifestyles in relation to energy technologies can be recognized.

The empirical data reveal a relationship between lifestyle typology and the prospective choice of heating systems based on fossil fuels or renewable energy. Figure 4 shows a different pronounced preference for renewable energies of the individual milieus. A bit surprising is that Traditionals and Nostalgics of former GDR - both milieus are classified as conservative and resistant to innovations - have installed more renewable energy systems

\footnotetext{
${ }^{1}$ Based on 274 specific data.

${ }^{2}$ Based on 426 specific data.

${ }^{3}$ In accordance with the Federal Statistical Office of Germany.
}

than more innovative lifestyles like the Well-Establisheds. In Figure 4 it is distinguished between fossil fuels and renewable fuels, meaning a more pronounced preference of the Well-Establisheds for environmentally friendly gas-fired boilers based condensing boiler technology disregard here. In the group of renewable energies wood pellets can be found - a preference of the Traditionalists towards the classical fuel wood influences the results, too.

Table 2. Descriptive statistics $(N=429)$.

\begin{tabular}{|c|c|c|}
\hline $\begin{array}{l}\text { Demographic } \\
\text { characteristics }\end{array}$ & Value & Frequency \\
\hline \multirow{2}{*}{ Sex } & female & $213(49.7 \%)$ \\
\hline & male & $216(50.3 \%)$ \\
\hline \multirow{9}{*}{$\begin{array}{l}\text { Household income } \\
(€)\end{array}$} & $<500$ & $7(1.6 \%)$ \\
\hline & $500-<900$ & $5(1.2 \%)$ \\
\hline & $900-<1,500$ & $31(7.2 \%)$ \\
\hline & $1,500-<2,000$ & $44(10.3 \%)$ \\
\hline & $2,000-<2,500$ & $44(10.3 \%)$ \\
\hline & $2,500-<3,000$ & $30(7.0 \%)$ \\
\hline & $3,000-<3,500$ & $28(6.5 \%)$ \\
\hline & $=>3,500$ & 85 (19.8\%) \\
\hline & not specified & 155 (36.1\%) \\
\hline \multirow{5}{*}{ Education } & no graduation & $1(0.2 \%)$ \\
\hline & School leaving certificate & $198(46.2 \%)$ \\
\hline & A-level (German Abitur) & $56(13.1 \%)$ \\
\hline & University degree & $173(40.3 \%)$ \\
\hline & not specified & $1(0.2 \%)$ \\
\hline \multirow{3}{*}{ Employed } & yes & 214 (49.9\%) \\
\hline & no & $212(49.4 \%)$ \\
\hline & not specified & $3(0.7 \%)$ \\
\hline
\end{tabular}

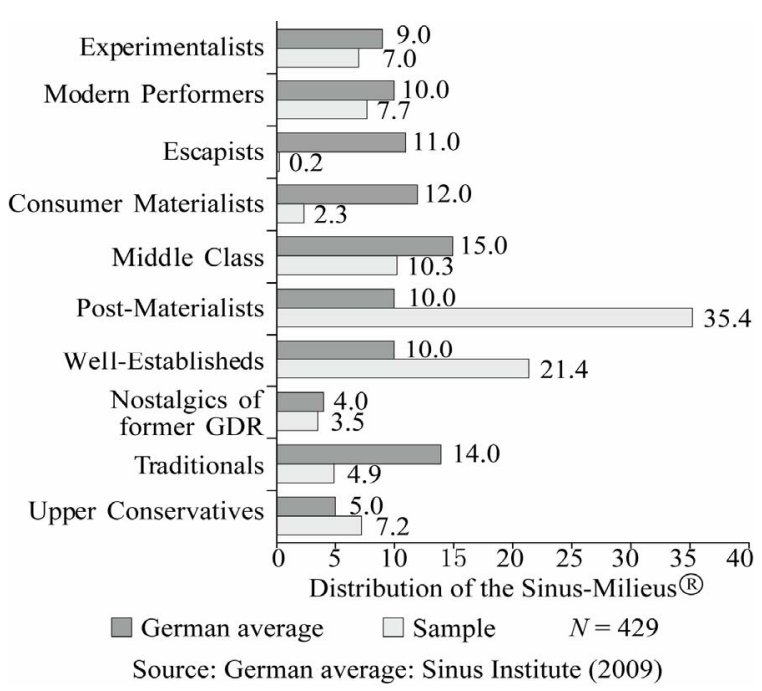

Figure 3. Frequencies of Sinus-Milieus $₫$ in comparison to the average in Germany. 
In addition, two extremes can be identified with respect to the preference of using fossil fuels: The SinusMilieu ${ }^{\circledR}$ Middle Class shows a clear preference for fossil fuels (80\%). In contrast, only $40 \%$ of the Modern Performers prefer fossil fuels. Both Sinus-Milieus ${ }^{\circledR}$ (Middle Class and Modern Performers) also represent important groups regarding the social diffusion of technological innovations. Furthermore, similar socio-demographic fac- tors (e.g. age) of both milieus facilitate a comparison. Therefore, the following presentation of the survey results will focus on the attitude of Modern Performers and Middle Class.

\subsection{Heating Systems in Use}

Classifying the currently used heating systems by type (Figure 5) provided the following results: Significant

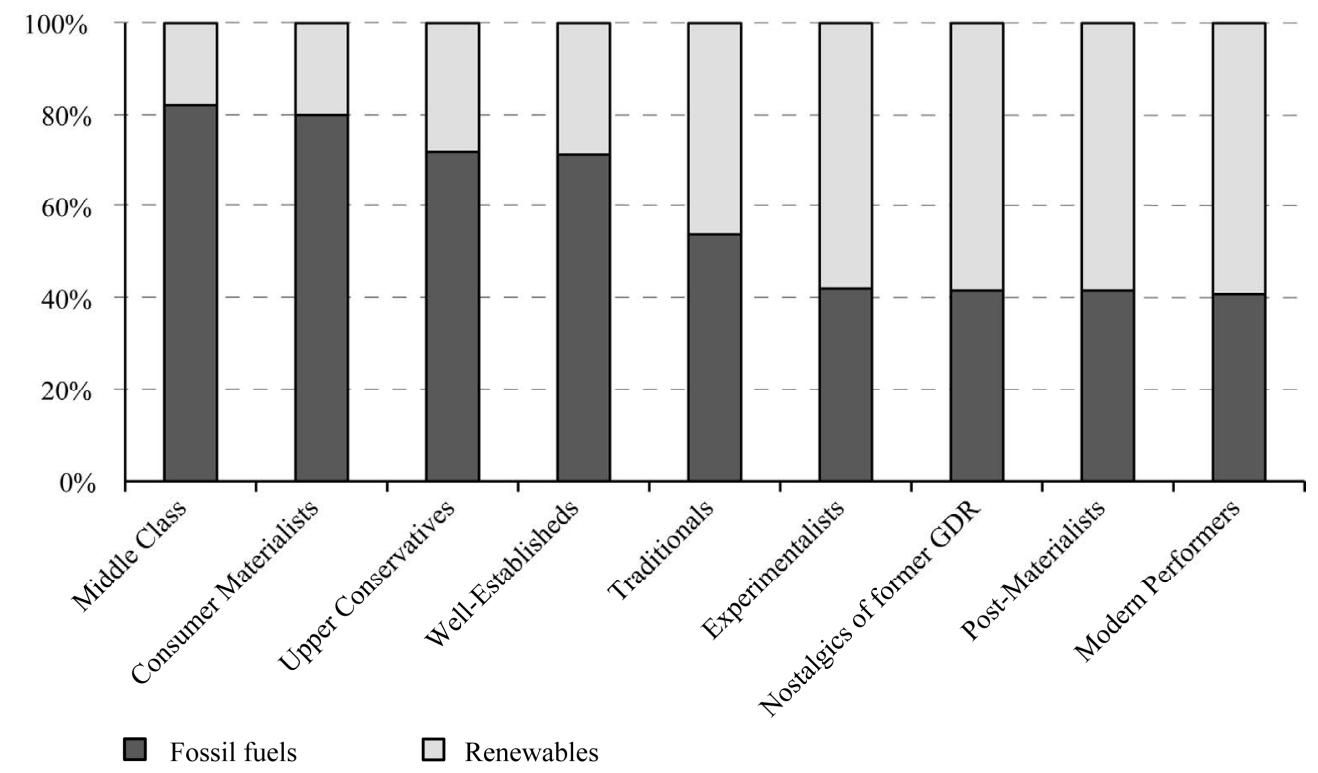

Figure 4. Relationship between specific Sinus-Milieus ${ }^{\circledR}$ and preference for fossil-fuelled heating systems. (Because of an insufficient number of cases the Sinus-Milieu ${ }^{\circledR}$ Escapists are not shown.) Source: Institute for Infrastructure and Resources Management, 2010.



Figure 5. Heating systems used in Germany, classified by Sinus-Milieus ${ }^{\circledR}$. Multiple answers were allowed. Source: Institute for Infrastructure and Resources Management, 2010. 
differences between the lifestyles can be noted with respect to the application of renewable energy technologies. The Modern Performers occupy a leading position: 21\% of them already use solar heating systems, $12 \%$ geothermal energy and $9 \%$ heat pumps. Only $11 \%$ of the Middle Class use solar heat, whereas geothermal energy and heat pumps are not used at all thus far. An exception is the modern form of the renewable energy source wood. Wood pellets are used more than twice as much by the Middle Class (7\%) as by Modern Performers (3\%).

In both milieus natural gas fuelled heating systems represent the commonly used systems. Gas boilers are increasingly used in combination with innovative technologies and not just as a single heat source.

The differences between the two milieus are minor in the case of gas, whereas the Modern Performers (24\%) use oil much less frequently than the Middle Class (43\%).

In the survey, no one has yet chosen small combined heat and power plants (CHPs). The survey reflects the fact that night storage heaters and coal heating are declining technologies in Germany. Only the Middle Class still uses coal-burning stoves (7\%) and night storage heaters (2\%). District heating plays only a minor role (Modern Performers 3\%, Middle Class 2\%). This is primarily due to the fact that district heating is not available in all cities in Germany, less because consumers reject the technology itself.

The presented variances in the use of energy sources show the existence of milieu-specific differences and underline the above-mentioned hypothesis. However, the extent to which technical data such as age of the building, type of the building and location of the house influence the decision for or against a certain technology still has to be analysed. This type of investigation will be conducted as part of the second part of a project that will be funded by the German Ministry of Education and Research during the next five years.

\subsection{Preferred future Heating Systems}

Because of the current modernization status of household heating systems, not only the status-quo but also the question as to which heating systems will be preferred in the future is relevant. The set of possible answers was generally the same as for the status-quo. Only coalburning stoves and night storage heaters were excluded. These systems are declining and are thus no longer taken into consideration.

A main trend which can be indentified is a declining interest in fossil fuels. However, natural gas will still play an important role for both milieus in the future. A significant difference is shown with respect to heating oil. Only $12 \%$ of the Modern Performers are interested in using it, in contrast $34 \%$ of the Middle Class still wants to use heating oil.

There is a positive attitude toward renewable technologies. Although the Modern Performers demonstrate their role as leaders in innovation adaption, the Middle Class also exhibits an interest in the use of geothermal energy (7\%), heat pumps (5\%) and solar heat (25\%) in particular.

District heating is preferred by $9 \%$ of the Modern Performers, whereas the Middle Class does not appear interested in district heating as a future heating system.

A positive trend can be noted for small CHPs. The Middle Class (7\%) seems more open towards small CHPs in their buildings than Modern Performers (3\%).

\section{Discussion and Conclusions}

\subsection{Lessons Learnt and Further Research Perspectives}

The empirical approach described in this article investigates energy-related investment decisions of private households. The main outcome of the survey results is an apparent connection between lifestyles (here: the SinusMilieus $\left.{ }^{\circledR}\right)$ and investment behaviour with regard to heating systems. Therefore lifestyles were chosen as a means to measure behaviour like the investment in energy technologies, which can be related to attitudes like ecology-minded (e.g. Modern Performers) or conservative (e.g. Middle Class). But using lifestyles instead of socio-demographic data (e.g. age or size of household) has also disadvantages. One disadvantage is the continuous process of change in a society. The social transformation leads to a different composition of lifestyles. The used Sinus-Milieus ${ }^{\circledR}$ are validated empirically every year, due to changing values, preferences and lifestyle-structures. Thus, they can be used as a realistic instrument for the description of the social reality.

The Sinus-approach also has the advantage - compared to other classifications of milieus - to provide spatially referenced lifestyle data for Germany. Such highly resolved spatially data on lifestyles can be linked with technical data and therefore allow analysing the investment behaviour as a function of living conditions like building type or location of the house. However, using the Sinus-Milieus ${ }^{\circledR}$ has a major disadvantage: The classification of 10 milieus leads to a realistic picture of the German society but complicates representative empirical surveys. The varied allocation of the Sinus-Milieus ${ }^{\circledR}$ in society causes diverse group sizes in representative samples, especially if the survey addresses only a certain part of the population (in the present case house owners). The condition of homoscedasticity is thus not observed. To compensate this shortcoming, a judgment sample is needed which allows an equal representation of all milieu groups. Alternatively, with a larger sample size, a random 


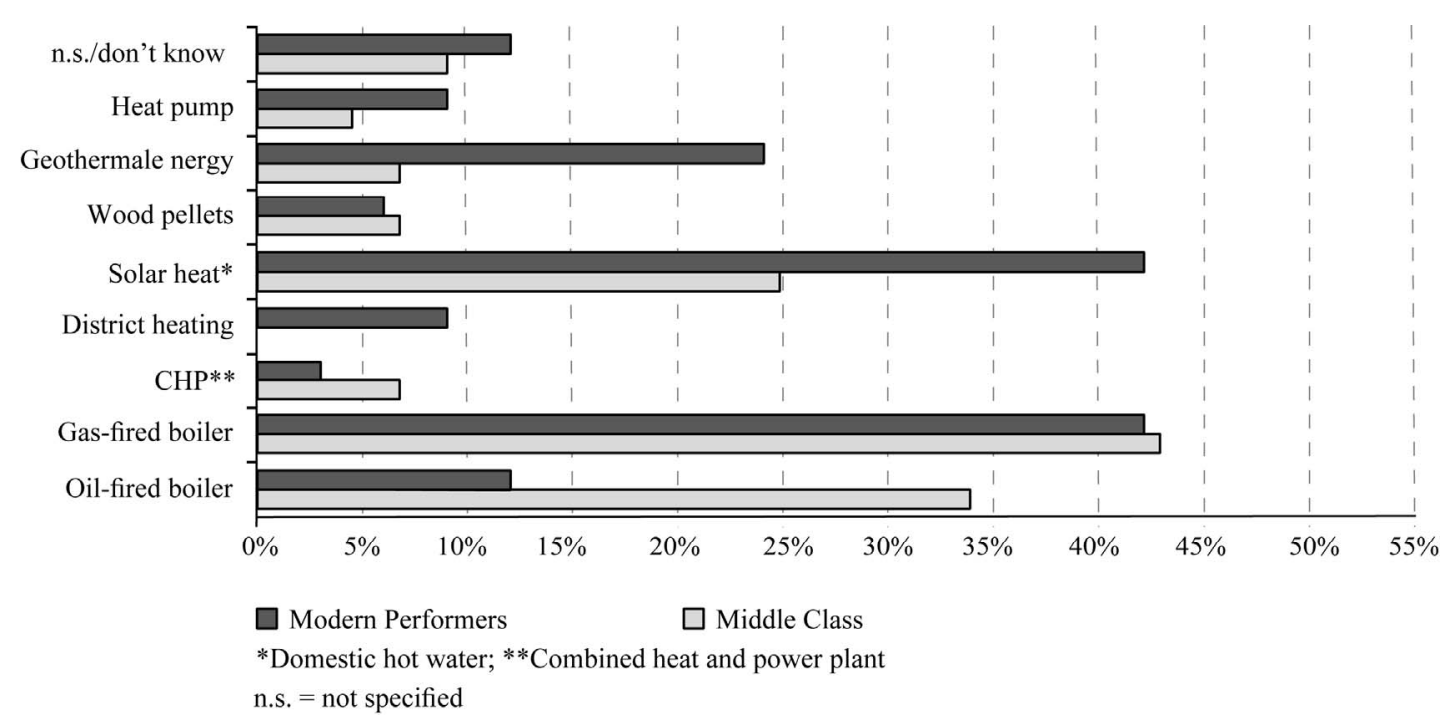

Figure 6. Preferences for specific heating technologies distinguished by Sinus-Milieus ${ }^{\circledR}$. Multiple answers were allowed. Source: Institute for Infrastructure and Resources Management, 2010.

deletion of over-represented milieu groups could be done.

Thus, the present survey will be re-conducted within one year in the course of the second part of a project ${ }^{4}$ funded by the German Ministry of Education and Research. The objective is to verify the empirical findings taking into consideration the mentioned constraints. The long-term scientific objective is the implementation of a computer-supported, agent-based simulation platform that enables researchers and decision makers to estimate the development of heat energy demand within the residential building sector with respect to individual investments $[28,29]$. Using such information, regional energy and climate concepts can be designed taken realistic approaches of action into account, and do not just consider energy technical advice. To achieve such an objective, further qualitative and quantitative surveys are planned to describe the agent-specific behaviour in a more detailed manner.

\subsection{Policy Implications}

As a main policy implication, this survey makes an important contribution to the discussion of environmental compatibility and sustainability. The results provide a "window of opportunity" for sustainable use of resources and energy consumption and indicate that policy makers should consider focusing on specific lifestyles for effective information campaigns. Communication processes which are directly or indirectly related to the overall concept of sustainability have to get linked to the various attitudes and behaviour patterns.

This study emphasizes the role of Social Leaders as

4"Path towards an efficient energy supply system - Development of a stakeholder-oriented municipal energy management system in Delitzsch (Germany)”. leaders in the adaption of innovations in the diffusion process of new energy technologies. As knows from literature [26] the Social Leaders are assumed as opinion leaders and people who influence social standards. Other milieus orient themselves by the Social Leaders and adapt their behaviour patterns. The less innovative milieus will adapt long-term to changing conditions due to social pressure. In the context of energy-related investment decisions this mean an increase of investments in energy-efficient technology and the use of renewable energies. To increase sustainability for a whole society, communication strategies should focus on Social Leaders. Thus, Social Leaders are a main target-group of environmental-social approaches for promoting energy efficiency improvements.

Furthermore, based on the observed link between lifestyles and decisions on energy technologies, predictions of energy trends in private residential buildings can be improved. Knowledge about development paths and spatial referencing of lifestyles allows the use of this information to promote sustainable consumption behaviour.

\section{Acknowledgements}

The empirical survey has been part of the "Path towards an efficient energy supply system - Development of a stakeholder-oriented municipal energy management system in Delitzsch (Germany)" Project, which was supported by the German Ministry of Education and Research. The authors gratefully acknowledge support by the Institute of Geography of the University of Leipzig.

\section{REFERENCES}

[1] European Environment Agency, “About Household Con- 
sumption,” 2011.

http://www.eea.europa.eu/themes/households/about-house hold-consumption

[2] M. Kleemann, R. Heckler, G. Kolb and M. Hille, "Die Entwicklung des Wärmemarktes für den Gebäudesektor bis 2050,” Schriften des Forschungs-zentrum Jülich, Reihe Umwelt, Jülich/Bremen, 2000.

[3] AGFW, "Strategien und Technologien einer pluralistischen Fern- und Nahwärmeversorgung in einem liberalisierten Energiemarkt unter besonderer Berücksichtigung der Kraft-Wärme-Kopplung und regenerativer Energien,” AGFW-Hauptstudie, Vol. 2, No. 1, Frankfurt a. M., 2001.

[4] A. Schuler, C. Weber and U. Fahl, "Energy Consumption for Space Heating of West German Households: Empirical Evidence, Scenario Projections and Policy Implications,” Energy Policy, Vol. 28, No. 12, 2000, pp. 877-894. doi:10.1016/S0301-4215(00)00074-4

[5] M. Blesl, A. Das, U. Fahl and U. Remme, "Role of Energy Efficiency Standards in Reducing $\mathrm{CO}_{2}$ Emissions in Germany: An assessment with TIMES,” Energy Policy, Vol. 35, No. 2, 2007, pp. 772-785. doi:10.1016/j.enpol.2006.05.013

[6] L. Lutzenhiser, "Social and Behavioral Aspects of Energy Use," Annual Review of Energy and the Environment, Vol. 18, 1993, pp. 247-289. doi:10.1146/annurev.eg.18.110193.001335

[7] S. Barr, A. W. Gilg and N. Ford, "The Household Energy Gap: Examining the Divide between Habitual - and Purchase-Related Conservation Behaviours,” Energy Policy, Vol. 33, No. 11, 2005, pp. 1425-1444. doi:10.1016/j.enpol.2003.12.016

[8] A. H. Perrels, W. G. van Arkel, K. F. B. de Paauw and W. O. Pellekaan, "Household Energy Demand in a Lifestyle Context - The ELSA Model,” ECN-C-95-099, Petten, 1996.

[9] P. Bourdieu, "Distinction: A Social Critique of the Judgement of Taste,” Harvard University Press, Cambridge, 1984.

[10] E. Rogers, "Diffusion of Innovations," The Free Press, New York, 2003.

[11] A. Vishwanath, "Impact of Personality on Technology Adoption: An Empirical Model," Journal of the American Society for Information Science and Technology, Vol. 56, No. 8, 2005, pp. 803-811. doi:10.1002/asi.20169

[12] F. Duchin, “Technology and Lifestyles: A Focus for Research in Ecological Economics," Plenary Address at the First ESEE Conference, St. Quentin, 23-25 May 1996.

[13] F. Duchin, "Lifestyle and Technology: How Much Difference Can They Make?” In: R. Pachauri and L. Kureshy, Eds., Population, Environment, and Development, Tata Energy Research Institute, New Delhi, 1997, pp. 303-309.

[14] P. Preisendörfer, "Umwelteinstellungen und Umweltverhalten in Deutschland,” Leske \& Budrich, Opladen, 1999.

[15] A. Baranzini and B. Giovannini (Ed.), "Energy Modelling beyond Economics and Technology,” Universté de Genève, Genèva, 1997.
[16] L. Schipper, S. Bartlett, D. Hawk and E. Vine, "Linking Life-Styles and Energy Use: A Matter of Time?” Annual Review of Energy, Vol. 14, 1989, pp. 273-320. doi:10.1146/annurev.eg.14.110189.001421

[17] F. Reusswig, "Lebensstile und Ökologie. Gesellschaftliche Pluralisierung und alltagsökologische Entwicklung unter besonderer Berücksichtigung des Energiebereiches,” IKO Verlag, Frankfurt a. M., 1994.

[18] D. Rink, "Lebensstile und Nachhaltigkeit Konzepte, Befunde und Potentiale,” Leske \& Budrich, Opladen, 2002.

[19] F. Prose and K. Wortmann, "Energiesparen: Verbraucheranalyse und Marktsegmentierung der Kieler Haushalte - Endbericht,” Vol. 1, Institut Für Psychologie, Universität Kiel, Kiel, 1997.

[20] K. Schuster and E.-D. Lantermann, "Lebensstilanalyse in der Naturschutzkommunikation: Ein Instrument zur Akzeptanzsteigerung für den Naturschutz,” Zeitschrift für Naturschutz und Landschaftspflege, Vol. 77, No. 3, 2002, pp. 116-119.

[21] G. Bodenstein, H. Elbers and A. Spiller, "Strategische Konsumentscheidungen: langfristige Weichenstellungen für das Umwelthandeln: Ergebnisse einer empirischen Studie,” Discussion Paper, Universität Duisburg, Duisburg, 1997.

[22] C. Tanner and S. Wölfing-Kast, "Restriktionen und Ressourcen nachhaltiger Einkaufsgewohnheiten: Segmentierung Schweizer Konsumenten und Konsumentinnen,” Umweltpsychologie, Vol. 6, No. 2, 2002, pp. 84-104.

[23] G. Schulze, "Die Erlebnisgesellschaft. Kultursoziologie der Gegenwart,” Campus Verlag, 1995.

[24] Umweltbundesamt, "Umweltbewusstsein und Umweltverhalten der sozialen Milieus in Deutschland,” DessauRoßlau, 2009.

[25] N. Schwarz and A. Ernst, “Agent-Based Modelling of the Diffusion of Environmental Innovations - An Empirical Approach,” Technological Forecasting and Social Change, Vol. 76, No. 4, 2009, pp. 497-511. doi:10.1016/j.techfore.2008.03.024

[26] S. Kleinhückelkotten, "Suffizienz und Lebensstile Ansätze für eine milieuorientierte Nachhaltigkeits Kommunikation,” Vol. 2, BWV, Berlin, 2005.

[27] Sinus Sociovision, "Mosaic-Milieus ${ }^{\circledR}$ : Lizensierte Adaption der Sinus-Milieus ${ }^{\circledR}, ” 2008$.

http://www.sociovision.de/uploads/tx_mpdownloadcenter /MOSAIC_Milieus_012008.pdf

[28] T. Wittmann, R. Morrison, J. Richter and T. Bruckner, “A Bounded Rationality Model of Private Energy Investment Decisions," Proceedings of the 29th IAEE International Conference: Securing Energy in Insecure Times, Potsdam, 7-10 June 2006.

[29] T. Wittmann and T. Bruckner, “Agent-Based Modeling of Urban Energy Supply Systems Facing Climate Protection Constraints,” Fifth Urban Research Symposium, Marseille, 28 June 2009. 